Arch. Microbiol. 104, 39-49 (1975)

(C) by Springer-Verlag 1975

\title{
Zoosporic Fungi from Tunisia, and the Seychelles Islands (Indian Ocean)
}

\author{
FREDERICK K. SPARROW \\ Botany Department, University of Michigan, Ann Arbor, Michigan
}

Received January 10, 1975

\begin{abstract}
Twenty-two zoosporic fungi were recovered from soil samples collected in Tunisia and in the Seychelles Islands in the Indian Ocean. One, Phlyctochytrium chand-
\end{abstract}

lerii is described as new. Most of the others are referred, sometimes tentatively, to existing species or genera.

Key words: Zoosporic Fungi - Soil - Phlyctochytrium chandlerii n. sp. - Morphology - Tunisia - Seychelles.

Information on the distribution of zoosporic fungi throughout the world is gradually being accumulated and, since in this process, new forms are appearing with great regularity, this sort of investigation is of considerable interest and value to students of these fungi. The present contribution, made possible by globe-trotting friends, presents data on soil zoosporic fungi from Tunisia and from the Seychelles, a remote group of islands in the Indian Ocean north of Madagascar at $4^{\circ} \mathrm{S}, 56^{\circ} \mathrm{E}$. No zoosporic fungi are known from the last-named locality nor from the desert sites in Tunisia.

\section{Fungi Collected}

1. Phlyctochytrium reinboldtae Persiel, Pine pollen bait, near "Bath of Antonius", Carthage, Tunisia; V.27.72.

The body of the sporangium was $20-25 \mu \mathrm{m}$ in diameter and bore 4-6 broad conical protuberances up to $10 \mu \mathrm{m}$ high by $5-7 \mu \mathrm{m}$ at the base. These produced the characteristic "morning star" appearance typical for this species. The subsporangial intramatrical apophysis was $5-7 \mu \mathrm{m}$ in diameter. No rhizoids could be detected coming from it owing primarily to the dense contents of the pollen grain. It seems likely that they were present.

2. Phlyctochytridium quadricorne (de Bary) Schroeter. Pine pollen; virgin forest soil, $2500^{\prime}$ elevation; Mahé, Seychelles; V.24.72.

The sporangia, armed with a terminal crown of 4 bipartite teeth, were $15-17 \mu \mathrm{m}$ broad by $10-12 \mu \mathrm{m}$. high. The intramatrical apophysis was strongly taprootlike and $5-7 \mu \mathrm{m}$ broad where it expanded just beneath the sporangium. The spherical zoospores, $6-7 \mu \mathrm{m}$ in diameter, bore a large, conspicuous, $4 \mu \mathrm{m}$ in diameter refractive globule.

3. Phlyctochytium africanum Gaertner. Pine pollen; near "Dido Castle", Carthage, Tunisia; V.27.72.

The fungus agrees in many respects with Gaertner's (1954). Only rarely, however, could more than one globule (Fig. 2) be seen in the zoospore. Furthermore, the papillae were more prominent (Fig.1). Just how significant these differences are awaits further study.

A Phlyctochytrium with several globules or granules in its zoospores was recovered on pollen grains from soil from the oasis of Chenine at Gebes, Tunisia; collected V.29.72. Its globose colorless smoothwalled sporangia (Fig. 3) were $27-35 \mu \mathrm{m}$ in diameter, with a distinctly thickened wall and $3-5$ sessile or slightly elevated pores and an ovoid $12 \mu \mathrm{m}$ in diameter apophysis. The zoospores (Fig.4) which were ovoid and $5 \times 3 \mu \mathrm{m}$, escaped individually through the pores.

Thus, one of these fungi has the taproot rhizoidal system characteristic of $P$. africanum but zoospores with one globule. The other has the zoospores of $P$. africanum but a subspherical, not taproot-like apophysis, which if it has rhizoids must be very delicate and certainly not like the coarse ones characterizing Gaertner's species. Koch (1957) has observed variations in the number of "lipid bodies" in zoospores of chytrids and cautions against too much taxonomic significance being accorded this character.

To be discussed at this point, too, is a fungus on pollen in beach soil from Praslin, the Seychelles (collected V.26.72) which was referred tentatively to Phlyctochytrium africanum. The mature sporangia are perfectly globose (Fig.5) with a smooth, thickened colorless wall and $3-6$ prominent, $5 \mu \mathrm{m}$ in diameter 


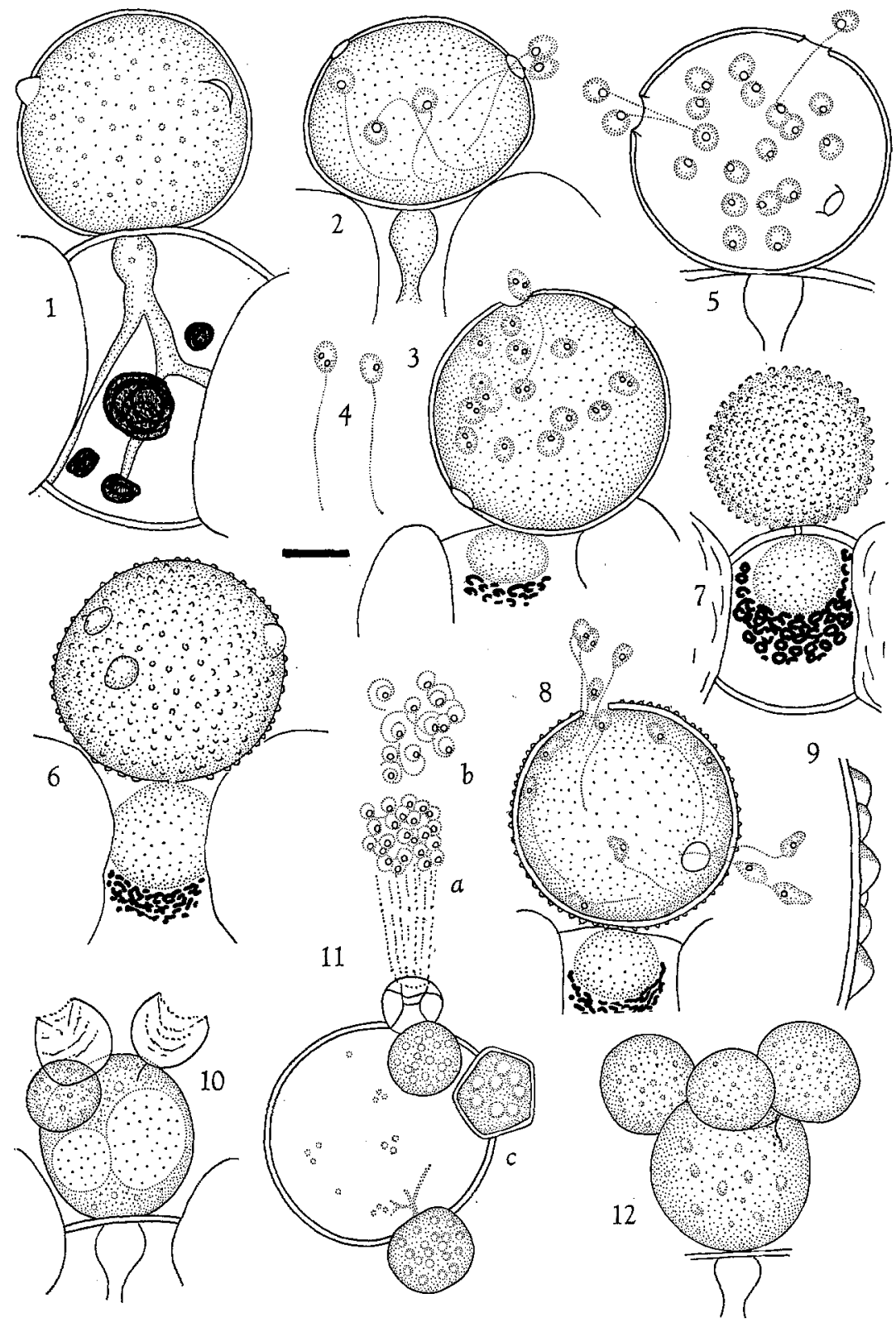

Figs. 1 and 2. Phlyctochytrium africanum on pine pollen

Fig. 1. Nearly mature sporangium with prominent discharge papillae and coarse endobiotic rhizoidal system

Fig. 2. Sporangium discharging uniguttulate zoospores

Fig. 3. Sporangium with spherical apophysis discharging zoospores with several globules

Fig. 4. Zoospores of Fig. 3

Fig. 5. Discharging zoosporangium like Fig. 2, but from Seychelles

Figs. 6-9. Phlyctochytrium chandlerii n. sp.

Figs. 6 and 7. Sporangia on pollen grains, Fig. 6 showing discharge papillae in verrucose wall

Fig. 8. Discharging sporangium with zoospores

Fig.9. Freehand rendition of sporangium wall showing verrucae

Figs. 10-12. Rhizophydium parasitic on thalli of Phlyctochytrium

Fig.10. Two empty sporangia and a maturing one epibiotic on host Fig. 11. Resting spore (c), 2 nearly mature sporangia and one which has just shot off group of zoospores $(a)$ which are shown about to swim away in (b)

Fig. 12. Three parasites on host chytrid. Bar beneath Fig. 4 indicates $10 \mu \mathrm{m}$ discharge papillae. The endobiotic part consists of a prominent subsporangial apophysis up to $7 \mu \mathrm{m}$ in diameter from the base of which a coarse unbranched (?) taproot-like rhizoid $2.5-3.0 \mu \mathrm{m}$ in diameter emerges. The zoospores are discharged through several $5 \mu \mathrm{m}$ in diameter sessile or slightly elevated pores formed upon the deliquescence of the papillae. They are spherical, $3.5-4.0 \mu \mathrm{m}$ in diameter and possess: a single basal refractive colorless globule, and posterior flagellum about $15 \mu \mathrm{m}$ long. No resting spores were found. This chytrid was heavily parasitized by another belonging to the genus Rhizophydium (see below).
The number of names applied to these smoothwalled multiporous Phlyctochytria is steadily mounting.

4. Phlyctochytrium chandlerii n. $\mathrm{sp}$. On pollen grains; soil from oasis of Chenini at Gebes, Tunisia V. 29.72.

Sporangium sessile, spherical, $12-20 \mu \mathrm{m}$ in diameter with an amber-colored slightly-thickened wall bearing very close-set slightly raised verrucae. Rhizoids delicate, branched, arising from a prominent, $15-17 \mu \mathrm{m}$ in diameter spherical intramatrical subsporangial apophysis. Zoospores ovoid, $3 \times 2 \mu \mathrm{m}$ with a minute colorless globule and $15 \mu \mathrm{m}$ long posterior flagellum; 
escaping through $3-5$ broad pores formed upon the deliquescence of the prominent $4-5 \mu \mathrm{m}$ broad by $3 \mu \mathrm{m}$ high papillae. Resting spores not observed.

Saprophytic on pine pollen; Oasis of Chenini, Gebes, Tunisia; V.29.72.

Named for its collector, Prof. David C. Chandler.

Type represented by Figs. 6-8.

The verrucose character of the wall (Figs. 6-9) at once distinguishes this species from congeneric forms.

The diversity of sporangial ornamentation evolved by members of this genus is indeed remarkable. The verrucae (Figs. 7 and 9) cannot be confused with the minute punctae present on such species as $P$. punctatum Koch.

Phlyctochytrium chandlerii sp. nov.

Sporangium sessile, sphaericum, pallide brunneo verrucosum $12-20 \mu \mathrm{m}$ diameter, papillis emittientibus 3-5 valde elevatis, 4-5 $\mu \mathrm{m}$ diameter; rhizoidale parum evolutum, ex apophyse sphaerica, $15-17 \mu \mathrm{m}$ diameter enascens. Zoosporae ovoideae, $3 \times 2 \mu \mathrm{m}$, globulo singulo parvo refractivo et flagello postico praeditae. Sporae perdurantes non obviae.

Planta in polline pini saprophytica in loco Tunisia dicto, per D. C. Chandler collecta.

Planta typica Figs. 6-8.

5. Phlyctochytrium irregulare Koch. Pine pollen; same locality as No. 2; Seychelles.

The mature sporangia were smooth-walled, somewhat ovate, $22-50 \mu \mathrm{m}$ long by $13-30 \mu \mathrm{m}$ high, with a single broad conspicuous discharge papilla up to $10 \mu \mathrm{m}$ in diameter terminating the narrower end. The whole structure (Figs. 33a, 34a and $35 \mathrm{~b}$ ) rested transversely on the substratum to which it was attached by an intramatrical branched rhizoidal system which emerged from an inconspicuous apophysis $4-6 \mu \mathrm{m}$ broad by $5-7 \mu \mathrm{m}$ long (Fig. $33 \mathrm{~b}$ ).

Zoospore discharge was an impressive process. At its inception the conspicuous papilla bulged slowly outwards (Fig. 34) expanding and assuming a somewhat globular contour carrying with it the mass of individually quiescent zoospores (Fig. 35a). There must have been in excess of a thousand of these in large sporangia. No evidence was found for the persistence of bits of the outer wall of the papilla on the expanding mass such as noted by Koch (1957). At the time when the spore mass had about equalled the size of the sporangium, individual zoospores began leaving the group (Fig.35). Initially, this took place at one point on the emerged passive mass but soon all assumed individual motility and swam away. The impression was strong that whatever was responsible for the coherence of the mass (a vesicle, "mucus"?) weakened first at one spot, usually the most distal point, and then was dissipated generally into the surrounding medium.

The zoospores (Fig. 36) were spherical, $2.5-3.0 \mu \mathrm{m}$ in diameter with a conspicuous droplet and $15 \mu \mathrm{m}$ long posterior flagellum. No nuclear cap was seen, contrary to Koch's observations. Just why this body is so conspicuous in some populations of zoospores and not in others needs study. No resting spores were found.

Our fungus in some of its features more nearly approached Willoughby's (1961) interpretation of Koch's species in that there were no minute punctations on the colorless sporangium wall, and in the limited extent of development of its subsporangial apophysis. The predominantly single large papilla, transverse position of the sporangium and method of zoospore discharge are outstanding features of this species and in these our material agreed with Koch's fungus.

6. Rhizophydium utriculare. Uebelmesser (Phiyctochytrium). Pine pollen, from same locality as No. 2; Seychelles.

The mature sporangia of this chytrid were predominantly narrowly obpyriform or clavate, i.e. resting on a narrow base. They were $25-35 \mu \mathrm{m}$ high by $20-30 \mu \mathrm{m}$ broad at the apex, tapering to $5-8 \mu \mathrm{m}$ at the base. The wall was smooth and colorless. A varying degree of angularity was imparted to the sporangium by the formation distally on it (rarely at the base) of $3-5$ prominent, $5 \mu \mathrm{m}$ broad discharge papillae (Fig.27). Upon their successive or simultaneous deliquescence the zoospores "bubbled out"; later emerged ones crept out by amoeboid movement (Fig.28). They were spherical, $2 \mu \mathrm{m}$ in diameter, with a minute refractive basal granule or droplet, and a $20 \mu \mathrm{m}$ long posterior flagellum. The intramatrical rhizoidal system was moderately developed, branched and arose, usually from a single axis, from a 3-7 $\mu \mathrm{m}$ broad by slightly longer subsporangial apophysis. No resting spores were seen.

The close resemblance of this organism to Rhizophydium utriculare Uebelmesser (1956) isolated on pollen by her from normal Australian soil and from saline soil from "North America" is indeed remarkable, except for the constant presence in the Seychelles material of an apophysis and a single globule in the zoospore. Karling's R. angulosum (1968) also bears some resemblance to it but in that species angularity is actually due to sporangial shape, not to the presence of papillae. There are less obvious differences as well. The Seychelles fungus is retained for the moment in Rhizophydium rather than trying to accomodate it in Phlyctochytrium. 
7. Rhizophydium sp. Parasitic on sporangia of the globose Phlyctochytrium discussed under No. 3; beach soil, Praslin, Seychelles; V.26.72.

This globose species (Figs. 10-12) was a voracious parasite of the Phlyctochytrium and eventually killed off the host completely in our cultures.

The sporangia were perfectly spherical, $10-15 \mu \mathrm{m}$ in diameter with a smooth, thin, colorless wall. The rhizoidal system was usually feebly branched, of limited extent, and arose from the tip of a short stalk inside the pollen grain (Figs. 10 and 11).

Zoospore discharge was unusual. At maturity, the zoospores were shot off in a clump with great speed to a distance of $10-20 \mu \mathrm{m}$ (Fig. 11a). Here, they remained motionless for a few minutes before drifting apart (Fig. $11 \mathrm{~b}$ ), uncoiling their flagella and swimming away. Instantly at discharge, the empty sporangium recoiled and retracted as a wrinkled somewhat collapsed structure still attached to the host plant (Figs. 10 and 11). It was evident that the wall had been split at the time of ejaculation of the spore mass. It did not, however, dissolve either wholly or in part.

Angular resting spores about $13-15 \mu \mathrm{m}$ broad with guttulate contents were almost constantly associated with the sporangia on the chytrid host and are assumed to belong the Rhizophydium (Fig. 11c). They could not, however, be made to germinate.

Barr (1971) and Karling (1964) have discussed chytrids in which partially or wholly deliquescing walls are involved in zoospore discharge. Forciful ejaculation of the zoospores, however, is evidently not found in their species.

8. Rhizophydium sp. Pine pollen, in sterile seawater and soil, from near beach; Praslin, Seychelles, V.26.72.

Inasmuch as soil in this collection was from near the beach line it was thought of interest to put a small sample in seawater instead of freshwater in setting up to culture. A single fungus was obtained by this method, a species of Rhizophydium (Figs. 29-32).

The epibiotic sessile sporangium was spherical to subspherical $26-30 \mu \mathrm{m}$ in diameter with a thin, colorless wall. Prior to zoospore cleavage the contents underwent a phase in which numerous refractive clods appeared (Fig.29). These gradually fragmented into successively smaller fractions until at the time of zoospore cleavage the contents were uniformly finely granular. Within the pollen grain there was a richly branched rhizoidal system of delicate elements emanating from a very short trunk. There were also on the upper part of the sporangium 1-2 very inconspicuous papillae $2.75 \mu \mathrm{m}$ broad by $1.5-2.0 \mu \mathrm{m}$ high (Fig. 30).

Upon discharge of the sporangium usually only one of the papillae deliquesced, at which time the zoospores moved out in a loosely aggregated column where at a short distance from the sporangium they assumed individual motility (Fig. 31). The emergence pore after discharge was nearly invisible. The zoospore was spherical, $2.5 \mu \mathrm{m}$ in diameter and bore a dull, not a refractive globule, and a $25 \mu \mathrm{m}$ long flagellum (Fig. 32). Forward progression of the zoospore was slow and was accompanied by a strong lateral vibration or "shuddering" of the body. No resting spores were seen.

Two features characterize this fungus, namely, the very small, inconspicuous papillae and the dull rather than refractive nature of the zoospore globule.

Since this fungus appeared only in soil samples set up with seawater it can perhaps be regarded as of marine origin.

9. Rhizophydium (?) condylosum Karling. Snake skin bait; same locality as No. 2; Seychelles.

It is difficult to describe the shape of sporangium of this fungus adequately except to say it is predominantly pyriform or obpyriform with irregularly placed small lobes (Figs. 13-15). This is somewhat in contrast to Karling's description of his fungus from Oceania in which the sporangia are said to be predominantly spherical. Yet his Fig. $2 \mathrm{~g}$ and $\mathrm{q}$ so nearly resemble those of the present fungus that these together with the exact similarity of their zoospores, occurrence on a keratin substratum, etc., favors placing the Seychelles fungus in his species, at least for the moment (Karling, 1968).

The sporangia were $22-32 \mu \mathrm{m}$ high by $8-20 \mu \mathrm{m}$ in greatest width with a thickened wall. Two to four protrusions or lobes, sometimes very broad, tended to produce a very irregular shape. The $2-4$ discharge papillae on mature sporangia (Figs. 14 and 15) either were placed at the tips of the lobes or strongly protruded from other parts of the sporangium. Occasionally, they were sessile. The rhizoidal system seemed in some instances to arise from a hemispherical apophysis (probably one of the lobes) or more commonly directly from the base. Whether such apophyses actually represented a portion of the zoospore cyst could not be determined. The rhizoids were delicate throughout and did not usually increase in diameter near the point of attachment to the sporangium (Fig.13). This was another departure in morphology from Karling's material where they were found to be tapering.

The zoospores were fully formed in the sporangium. At maturity they initiated movement and escaped through pores formed upon the deliquescence of the papillae (Fig. 14). They were elongate bodies, $3.5 \mu \mathrm{m}$ by $2 \mu \mathrm{m}$, with granular contents (not bearing a globule) and a $12-15 \mu \mathrm{m}$ long posterior flagellum. These zoospores so nearly resembled those of a parasitic 


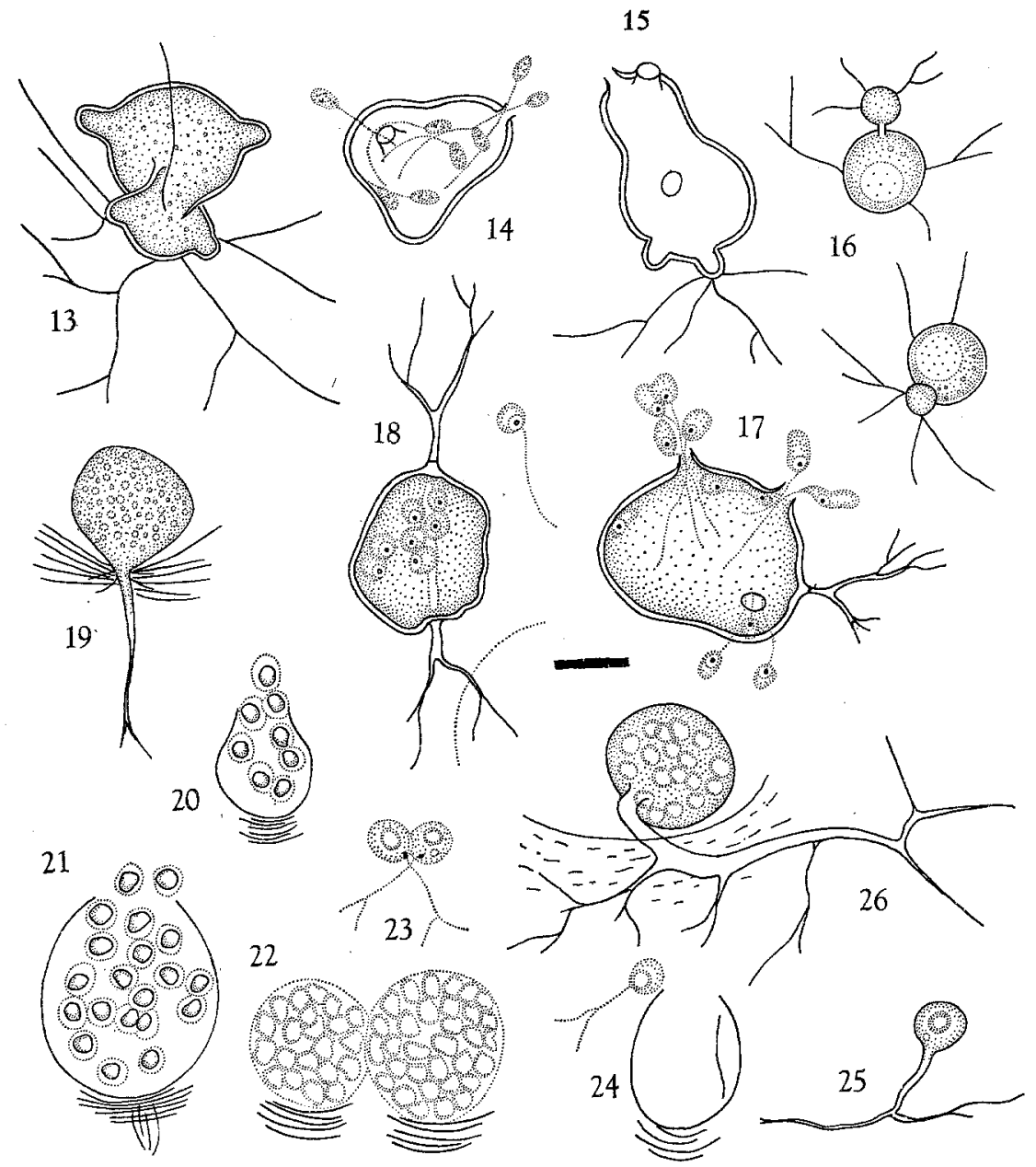

Figs. 13-18. (?) Rhizophydium condylosum

Figs. 13-16. From Seychelles

Fig. 13. Thallus

Fig. 14. Discharge of zoospores

Fig.15. Empty sporangium

Fig.16. Two resting spores with companion cells, upper with fertilization tube

Figs. 17 and 18. Sporangia from North Africa

Fig. 17. Discharge of zoospores Fig. 18. Sporangium with zoospores; note minute granule in vacuole of zoospore

Figs. $19-26$. Possible parasitized Rhizidium on human skin:

Fig. 19. Young thallus Figs. 20 and 21. Discharging spores Fig. 22. Two mature sporangia Fig. 23. Two germinated zoospores Fig. 24. Empty sporangium with one germinated zoospore

Fig. 25. Young stage in thallus formation

Fig.26. Nearly mature thallus. Black bar is $10 \mu \mathrm{m}$ endophytic Rozella that this feature, together with the thickened wall of the sporangium, lent some support to this hypothesis of parasitism.

Resting spores which were spherical and $10-12 \mu \mathrm{m}$ in diameter, or somewhat angular and $13 \mu \mathrm{m}$ by $10 \mu \mathrm{m}$ with thickened wall, central vacuole, and guttulate contents were found in association with this fungus (Fig.16). They differed somewhat from those of Karling's fungus in the larger size of their central vacuole and in the constant presence of an attached $3 \mu \mathrm{m}$ in diameter cyst. which like the resting spores had a delicate rhizoidal system (Fig. 16). A conjugation tube was clearly seen in some instances.

What may possibly be a related fungus (Figs. 17 and 18) was obtained on snake skin bait in soil from Tunisia (at Carthage, V.27.72). It had somewhat thick walled, less irregular sporangia, $12-15 \mu \mathrm{m}$ in diameter with $6-7$ raised discharge papillae and rhizoids which arose from one (possibly 2) place on the sporangium and which tapered distally. The zoospores were spherical, $4 \mu \mathrm{m}$ in diameter and bore a minute granule in a spherical vacuole-like structure, and $15 \mu \mathrm{m}$ long posterior flagellum (Figs. 17 and 18). They emerged individually by their own efforts through pores formed at the deliquescence of the papillae, usually undergoing amoeboid changes of shape during the process (Fig.17). It is not certain that this fungus relates either to the Seychelles or Oceania fungi.

10. Rhizophlyctis rosea (de Bary and Woronin) Fischer. On lense paper and cellophane bait; oasis of Chenini, Gebes; Carthage; Bardj El Hachichina, 10 miles south of Sfax; El Djem, in undisturbed desert; all Tunisia, V.29.72. Seychelles, same site as No. 2; V.24.72. Some of this material was undoubtedly endooperculate and hence can be referred to Karlingia.

11. Rhizidium sp. On human skin bait; same site as No. 2, Seychelles.

There seemed to be two distinct fungi present on the substratum and the possibility exists that the commonest one which resembled in its features Karling's (1968) interpretation of Gaertner's (1954) Rhizophydium racemosum, was, in fact, abnormal or parasitized material of the other.

The commonest form consisted of an epibiotic spherical, $15-25 \mu \mathrm{m}$ in diameter or somewhat subspherical and $15-24 \mu \mathrm{m}$ by $12-22 \mu$ sporangium 

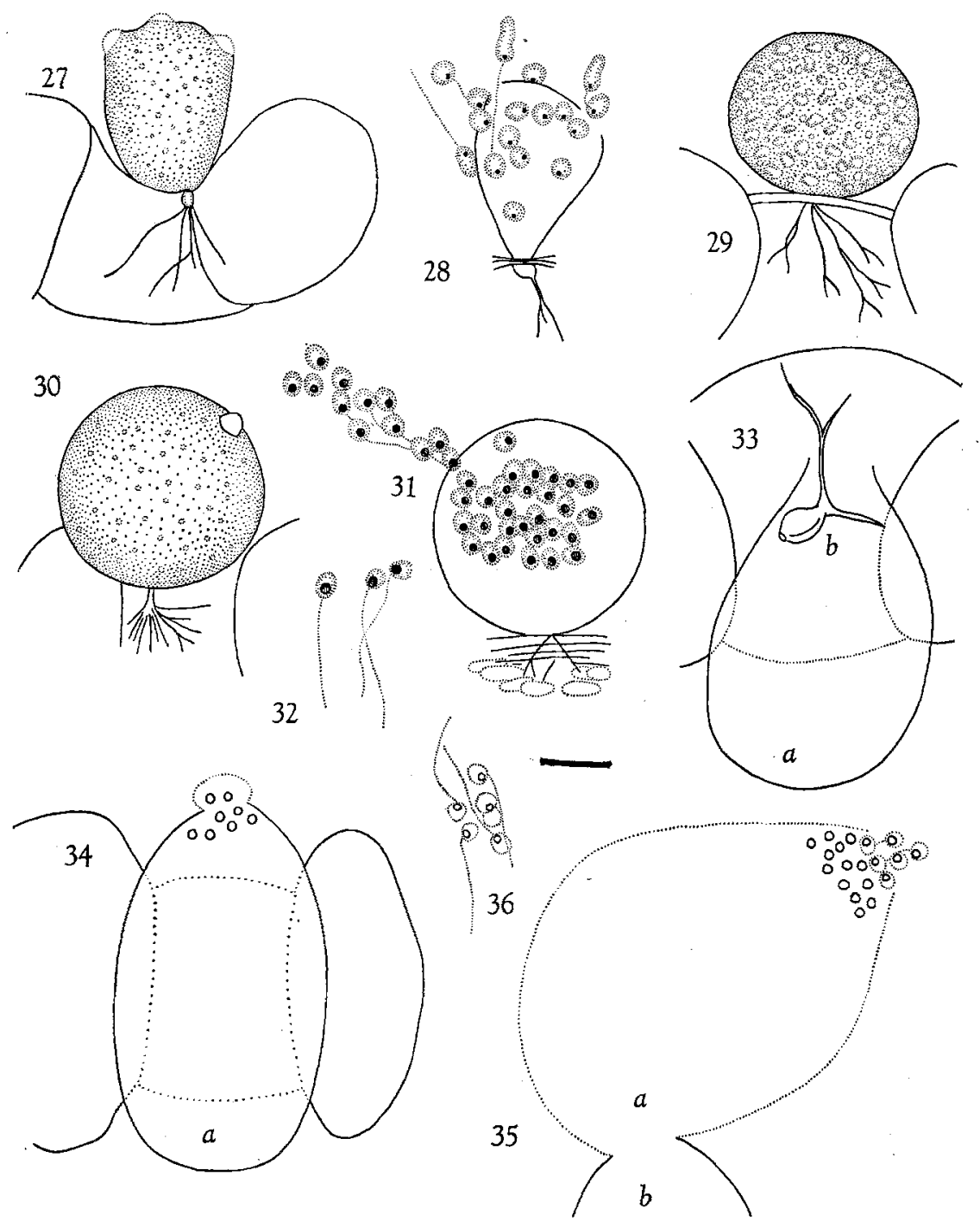

Figs. 27 and 28. (?) Rhizophydium utriculare on pine pollen

Fig. 27. Nearly mature papillate sporangium showing small endobiotic apophysis Fig. 28. Zoospore discharge Figs. 29-31. Rhizophydium (marine) on pine pollen

Fig. 29. Nearly mature sporangium

Fig. 30. Sporangium with one discharge papilla visible

Fig. 31. Discharge of zoospores

Fig. 32. Zoospores with dull globule in body

Figs. 33-36. Phlyctochytrium irregulare on pollen grains Fig. 33. (a) Empty sporangium showing apophysate rhizoidal system $(b)$ in pollen grain Fig. 34. Beginning of zoospore discharge, only the globules of a few spores near papilla shown, the main body of sporangium at $(a)$

Fig. 35. Mass of zoospores in vesicle $(a)$ which has emerged from body of sporangium $(b)$, only a few zoospores shown beginning to escape from vesicular mass Fig. 36. Free zoospores. Black bar is $10 \mu \mathrm{m}$ with thin colorless wall and a strongly developed taproot-like rhizoidal system which gave rise distally to numerous branches within the substratum (Fig. 19). The contents from early stages of development were filled with highly refractive bodies of various sizes and shapes. These structures became increasingly large and more angular as growth in size of the rudiment proceeded and just prior to spore discharge filled nearly the entire sporangium (Fig. 22). No discharge papillae were visible. At spore discharge the contents oozed out surrounded by a constantly expanding vesicular structure through a broad $6-10 \mu \mathrm{m}$ in diameter apical pore. The emerged mass of quiescent bodies which ultimately became twice the size of the sporangium itself, slowly dissociated into individual spores. Spores left in the sporangium simply drifted out (Figs. 20 and 21). Each of these was $4-6 \mu \mathrm{m}$ in diameter with a large irregular refractive body and occasionally a small basal granule. No flagella were seen. After some hours of searching among many of such quiescent bodies, only a few were found to have a flagellum and this was never seen to be active. Germination of the aflagellated bodies was frequent (Fig.23). In all instances they germinated in a typical Rhizidium-like manner, i.e., by the formation of a strong taproot-like axis from which emerged distally numerous rhizoids (Figs. 24-26). No resting spores were seen.

Only fragmentary observations could be made on the second fungus since it occurred very infrequently. The sporangia were nearly spherical, $12 \mu \mathrm{m}$ by $10 \mu \mathrm{m}$, with a taproot-like rhizoidal system, and at discharge of the zoospores the whole apex became involved in the production of a vesicular body which surrounded the emerging mass of quiescent zoospores. The latter were spherical, $2.5-3.0 \mu \mathrm{m}$ in diameter, with a minute 


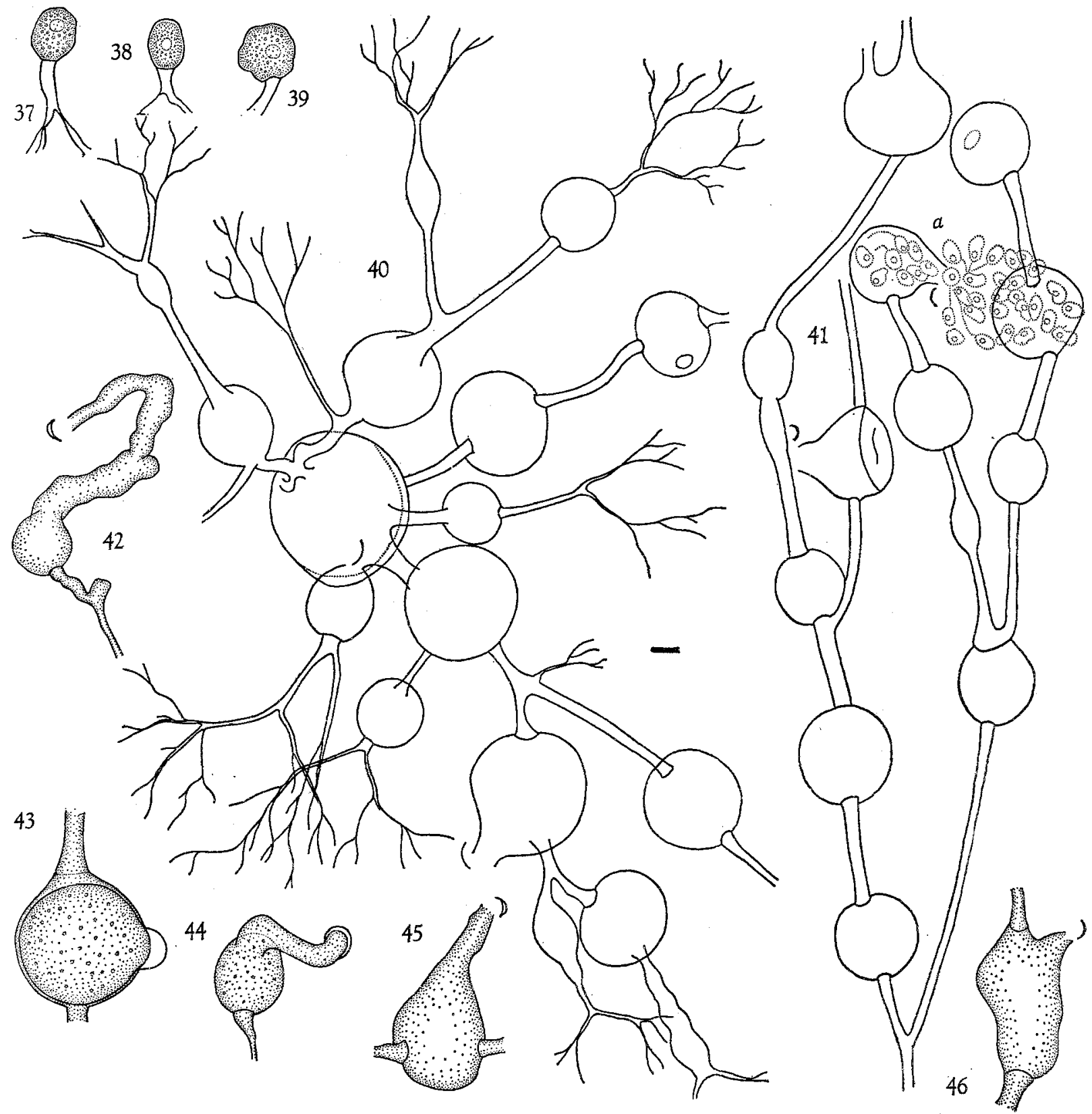

Figs. 37-46. (?) Septochytrium sp. on cellophane: Figs. 37-39. Resting spores. Fig.40. Outlines of radially organized thallus with spherical sporangia, peripheral tufts of rhizoids. Fig.41. Portion of a thallus showing cylindrical segments devoid of rhizoids, operculate zoosporangia, one of which is discharging at (a). Fig. 42. Operculate sporangium with long discharge tube. Fig. 43. One with sessile discharge papilla. Fig. 44 . Nearly mature sporangium. Figs. 45 and 46.

Empty ones with persistent opercula. Black bar is $10 \mu \mathrm{m}$

single droplet and posterior flagellum. They assumed motility upon the dissolution of the vesicular material in the medium.

The strong impression is given here that we are dealing in the first instance with some sort of abnormal development, caused perhaps by some sub-microscopic invader and the same impression is given by both Gaertner's and Karling's illustrations of their fungi. Only further studies of more material will clear up this rather confused picture.

12.? Septochytrium sp. Cellophane bait; same site as No. 2, Seychelles.

The general aspect of this strongly polycentric fungus can be observed in Fig. 40. It will be seen that there is a definite radial organization of the thallus centered around a large spherical $60 \mu \mathrm{m}$ in diameter 
(empty) sporangium. Radiating from the latter are isodiametric rigid elements almost devoid of rhizoids (Figs. 40 and 41) which bear intercalary operculate sporangia. Rarely, there are irregular swellings. Primarily at the tips of the swollen elements (immature sporangia) there are tufts of much-branched delicate rhizoids.

The predominantly intercalary and spherical nonapophysate sporangia were $35-60 \mu \mathrm{m}$ in diameter with one sessile (Fig.43), occasionally raised (Fig.46) or tubular (Figs. 42, 44 and 45) discharge papilla. The latter was surmounted by a convex operculum $8-10 \mu \mathrm{m}$ in diameter which was thrown back upon the emission of the zoospores (Fig. 41a). The latter emerged in a loose clump which dissociated as the individuals assumed individual motility. They were somewhat elongate $5-7 \mu \mathrm{m}$ by $3-4 \mu \mathrm{m}$ with a small colorless globule and posterior flagellum. Rarely, what appeared to be internal proliferation was observed (Fig. 43).

Brownish, ellipsoidal, somewhat irregular, and $14-17$ by $20-22 \mu \mathrm{m}$ (rarely spherical) resting spores, with thickened wall and small vacuole in the coarse contents were formed in great numbers on delicate much-branched rhizoids (Figs. 37-39). Their connection with the coarse polycentric thallus was conjectured from the constant association of the two, but could not be absolutely determined. Their germination was not observed.

Affiliations of this fungus with such coarse polycentric operculate forms as Nowakowskiella crassa Karling, $N$. profusa Karling, Septochytrium marilandicum Karling and Septochytrium macrosporum Karling have been considered. The apparent absence of septa in the vegetative parts would seem to ally it with Nowakowskiella. However, its pronounced radial type of organization centering on a conspicuous reproductive element, a sporangium, a feature well shown in Berdan's (1939) figure of a complete thallus of the generic type, $S$. variabile, the great rarity of irregular swellings, and of rhizoids, except at the periphery, impart a different aspect from that found in a species of Nowakowskiella. A similar situation in Septochytrium macrosporum Karling, led Karling (1942) to place his fungus in Septochytrium rather than Nowakowskiella, in spite of the lack of septa in the vegetative parts.

Except for the uniguttulate rather than granular zoospore contents and the lack of an endooperculum the Seychelles material is in close agreement with Willoughby's (1964) interpretation of Karling's Septochytrium marilandicum. Here too, emphasis has been placed by Willoughby on the radial organization of the thallus.
13. Catenophlyctis variabilis Karling. Snake skin bait; sand from off main desert road, El Djem; soil from rim of pit margin of pit house, Hotel Sidi Driss; Tunisia; V.29.72.

Excellent material of this striking chytridiomycete was obtained from both sites and has been readily maintained on snake skin, fingernail parings, bovine blood fibrin, etc. It has not as yet been cultivated on cellulisic materials as reported by Karling (1965).

Karling's papers on various phases of this fungus $(1947,1951,1965)$ present many interesting features on its morphology and development and possible life history. Since the African material was never brought into single spore culture observations were limited to supplementary observations on morphology and resting spore germination.

Thalli bearing great numbers of resting spores were dried on their substratum on cover glasses and stored away for seven months, after which water and new bait were added and a series - of van Tieghem cells set up, using these cover glasses. Within $50 \mathrm{~min}$ germ tubes had started to crack open the resting spore walls and 20-30 min later swimming zoospores were seen (Figs. 47 and 48 ). Within $4 \mathrm{hrs}$ the mount was swarming with zoospores. $24 \mathrm{hrs}$ after the original wetting of the dried material, many young polycentric thalli (Fig. 51) and somewhat fewer monocentric thalli (Figs. 49 and 50) were observed. Within another $24 \mathrm{hrs}$ some of the monocentric thalli had produced zoospores $7 \mu \mathrm{m}$ by $4 \mu \mathrm{m}$, with a conspicuous nuclear cap (Fig. 52). At this time, too, numerous resting spores were found on developing polycentric thalli (Fig. 53).

The speed of germination of the resting spores and formation of new ones evidently is an adaptation to the environment, well suited for ensuring survival of the organism under the rigorous desert conditions imposed upon it. Since in this particular area there are numbers of goats, camels, etc. constantly moving along the desert trail and around the pit houses, availability of nutritive keratin substrata would be assured. Indeed, there must be a variety of fungi present in such sites which have similar nutritive capabilities.

The general features of the life history of Catenophlyctis as outlined by Karling in which there are two types of thalli, monocentric and polycentric, in the life history, and an apparent lack of sexuality, recalls a wholly similar situation prevailing in the chytridiomycete family Physodermataceae containing the genera Physoderma and Urophlyctis. These are obligate parasites of vascular plants and have not as yet been cultured apart from their hosts. The monocentric thalli of these fungi were long considered by this writer to be gametangia and such was shown to 


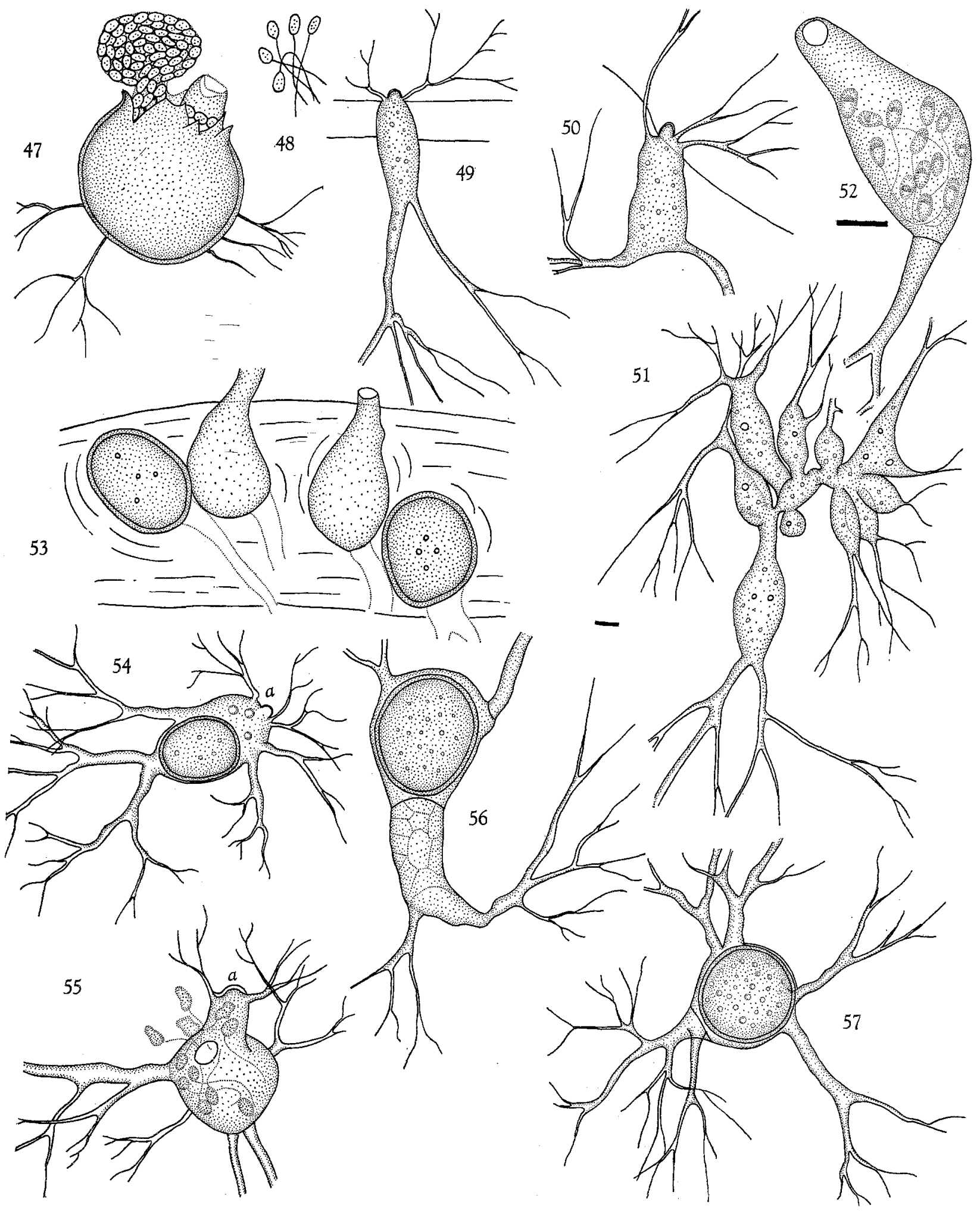

Figs. 47-53, Catenophlyctis variabilis on snake skin. Fig. 47. Germinating resting spore with two discharge tubes, only one of which functions. Fig. 48. Zoospores. Figs. 49 and 50. Appendiculate 24-hr-old monocentric thallus from R. S. zoospores. Fig. 51. Polycentric 24-hr-old polycentric thallus from R. S. zoospore. Fig. 52. Monocentric 48-hr-old thallus with zoospores, note higher magnification bar. Fig.53. Resting spores and empty sporangia, 48 hrs old. Figs. 54-57. Blastocladiella (?) stubenii on snake skin. Fig. 54. Appendiculate thallus with resting spore, zoospore cyst at (a). Fig. 55. Discharging appendiculate $(a)$ sporangium. Fig. 56. Rare stalked thallus with resting spore. Fig. 57. Resting spore thallus with zoocyst out of sight. Black bar by Fig. 52 is $10 \mu \mathrm{m}$; below Fig. 51, also $10 \mu \mathrm{m}$, and applies to all other figures except Fig. 52 
be true by Lingappa (1959) for Urophlyctis pulposa. Sufficient definitive evidence has not as yet been found to substantiate absolutely gamete production by monocentric thalli of Physoderma. Further, only limited data have as yet been collected on the types of thalli produced by zoospores from a single resting spore and hence the "totipotent" concept cannot be applied to Physoderma as it has been by Karling, here in Catenophlyctis.

No data on the occurrence of sexuality in Catenophlyctis can be contributed here except to say that at the germination of the resting spores in the aforementioned "gross cultures" in van Tieghem cells, swarmers of two sizes were present and that there was clumping of these with one another.

14. Blastocladiella (?) stubenii Couch and Whiffen. Same sites and substrata as No.13; also, Bardj El Hachichina 10 miles south of Sfax, Tunisia.

Occurring among thalli of Catenophlyctis on snake skin was a series of monocentric forms seen primarily in the resting spore stage. Although these resting spores bore a close resemblance to those of Catenophlyctis in shape, color, wall and contents, they differed markedly in being on strictly monocentric thalli and in lying loosely in their container (Figs. 54-57). Usually there was on this thallus a hemispherical cyst interpreted as being part of the cytospore of the swarmer giving rise to the thallus (Figs. 54a and 55a). Occasionally, thin-walled, colorless, monocentric thalli were seen which in one case was functioning as a zoosporangium (Fig. 55). The well-developed basal cell with holdfasts and resting spore shown in Fig. 56 was rarely found.

The usual thalli observed suggests affinity with Stüben's (1939) Sphaerocladia variabilis, particularly in the retention of a portion of the cyst of the zoospore (Stüben, 1.c., Fig.4). Zoosporangia were rare and as indicated, only one was found discharging zoospores. The latter were $6 \mu \mathrm{m}$ by $3 \mu \mathrm{m}$, with granular, colorless contents and were posteriorly uniflagellate. No "side body" was seen. They escaped through a $5 \mu \mathrm{m}$ in diameter sessile pore. No further stages were observed and whether these "sporangia" were gametangia or zoosporangia could not be determined.

The rapidity with which this fungus formed resting spores and the predominance of this stage recalls not only the previous fungus (Catenophlyctis) but also Blastocladiopsis. All these organisms appear highly adapted by quick resting spore formation to survive under rigorous desert, conditions where free water is only infrequently available, and then for highly variable lengths of time.

It is evident that there exists a series of Blastocladiella spp. which differ from Matthews' concept of the genus in several respects. Blastocladiella stubenii Couch and Whiffen, B. anabaenae Canter and Willoughby, B. novae-zeylandiae Karling, $B$. brittanica Horenstein and Cantino and the present fungus all agree in being predominantly without a basal cell. Furthermore, all save B. britannica are appendiculate, i.e., an unexpanded portion of the encysted zoospore persists on the developing thallus as in some chytrids. There are differences between these species in such characters as pitted (only B. britannica) or unpitted resting spores, cytoplasmic pigmentation (yellowish in B. novae-zealandiae and $B$. britannica), etc. Unfortunately, the resting spores of the aforementioned species (except $B$. stubenii) are either unknown or have not been germinated. When this highly important information has been obtained it might prove feasible to segregate them in a subgenus Sphaerocladia or Clavochytridium, whichever has priority, or even to elevate them to generic rank. Couch and Whiffen (1942) have discussed this small but interesting group of fungi and have given their reasons for reducing both Sphaerocladia and Clavochytridium to synonymy under Blastocladiella.

15. Allomyces javanicus var. javanicus Kniep. Hemp seed bait, soil; same site as No. 8, Seychelles.

Resting spores of the Allomyces, which were for the most part $50 \mu \mathrm{m}$ high by $35 \mu \mathrm{m}$ broad, were attacked by some organism which caused them to enlarge to as much as $83 \mu \mathrm{m}$ by $75 \mu \mathrm{m}$. This expansion took place after the wall pitting had been laid down and rendered them conspicuous objects among a population of normal spores. Dark plasmodium-like cytoplasm, often with large vacuoles appeared in many affected resting spores, but no reproductive structures were ever found.

16. Allomyces sp. Desert sand, El Djem, Tunisia, V.29.72.

17. Leptolegniella exosporus Kane. Snake skin bait, soil, same site as No. 15, Seychelles.

The surface mycelium of this strongly keratinophilic fungus was extensive and profusely branched. Branched or unbranched cylindrical sporangia arose from the surface of the substratum and bore one to two rows of primary zoospores. The latter escaped individually as elongate bodies and after a period of feeble swimming encysted. From each of the cysts emerged after a varying interval of rest a protoplast which developed two "laterally" placed flagella which were oppositely directed. A unique feature of the sporangial wall was the presence of spiral thickenings on the inner surface. Such thickenings were also present on the hyphal-like structures bearing single rows of thick-walled spherical parthenospores ("oospores"). 
Although it has only been reported three other times Leptolegniella exosporus is evidently widespread, since it was originally described from Indiana (Kane, 1966) and has subsequently been found in Texas, Oceania (Pitcairn Island) and now the Seychelles islands in the Indian Ocean.

Acknowledgements. I am greatly indebted to Dr. David C. Chandler for the soil samples from Tunisia and to Marilyn Everett Wilson who brought me samples from the Seychelles, collected by D. M. Messersmith.

\section{References}

Barr, D. J. S. : Rhizophydium patellarium and $R$. capillaceum (Chytridiales). Canad. J. Bot. 49, 1497-1502 (1971)

Berdan, H.: Two new genera of operculate chytrids. Amer. J. Bot. 26, 459-463 (1939)

Couch, J. N., 'whiffen, A. J.: Observations on the genus Blastocladiella. Amer. J. Bot. 29, 582-591 (1942)

Gaertner, A.: Beschreibung dreier neuer Phlyctochytrien und eines Rhizophidium (Chytridiales) aus Erdboden. Arch. Mikrobiol. 21, 112-126 (1954)

Kane, W. D.: A new species of Leptolegniella. Mycologia (N. Y.) 58, 905-911 (1966)

Karling, J. S.: A new chytrid with giant zoospores: Septochytrium macrosporum sp. nov. Amer. J. Bot. 29, $616-622(1942)$

Prof. Dr. F. K. Sparrow

Botany Department, University of Michigan

Ann Arbor, Michigan 48104, U.S.A.
Karling, J. S.: Keratinophilic chytrids. II. Phlyctorhiza variabilis n. sp. Amer. J. Bot. 34, 27-32 (1947)

Karling, J. S.: Polycentric strains of Phlyctorhiza variabilis. Amer. J. Bot. 38, 772-777 (1951)

Karling, J. S.: Indian chytrids. I. Eucarpic monocentric species. Sydowia, Ann. Mycologici 17, 285-296 (1964)

Karling, J. S.: Catenophlyctis, a new genus of the Catenariaceae. Amer. J. Bot. 52, 133-138 (1965)

Karling, J. S.: Zoosporic fungi of Oceania. III. Monocentric chytrids. Arch. Mikrobiol, 61, 112-127 (1968)

Koch, W. J.: Two new chytrids in pure culture, Phlyctochytrium punctatum and Phlyctochytrium irregulare. J. Elisha Mitchell scient. Soc, 73, $108-122$ (1957)

Lingappa, Y.: Sexuality in Physoderma pulposum Wallroth. Mycologia (N. Y.) 51, $151-158$ (1959)

Stüben, H.: Ưber Entwicklungsgeschichte und Ernährungsphysiologie eines neuen niederen Phycomyceten mit Generationswechsel. Planta (Berl.) 30, 353-383 (1939)

Uebelmesser, E. R.: Über einige neue Chytridineen aus Erdboden (Olpidium, Rhizophidium, Phlyctochytrium und Rhizophlyctis). Arch. Mikrobiol. 25, 307-324 (1956)

Willoughby, L. G.: The ecology of some lower fungi at Esthwaite Water. Trans. Brit. Mycol. Soc. 44, 305-332 (1961)

Willoughby, L. G.: A study of the distribution of some lower fungi in soil. Nova Hedwigia 7, 133-150 (1964) 